\title{
Antena mikrostrip berpolarisasi lingkaran pada daerah ultra high frequency dan super high frequency
}

\author{
Nurjanijan Madhatillah"1, Hepi Ludiyati ${ }^{2}$, Bagus Edy Sukoco ${ }^{3 *}$, Yaya Sulaeman ${ }^{4}$ \\ ${ }^{1,2}$ Jurusan Teknik Elektro, Politeknik Negeri Bandung \\ Jl. Gegerkalong Hilir, Ds. Ciwaruga, Kabupaten Bandung Barat, Jawa Barat, Indonesia \\ ${ }^{3,4}$ Pusat Penelitian Elektronika dan Telekomunikasi, Lembaga Ilmu Pengetahuan Indonesia \\ Jl. Cisitu, Sangkuriang Bandung, Jawa Barat 40135, Indonesia \\ ${ }^{1}$ nurjanijan.madhatillah.tcom417@polban.ac.id, ${ }^{2}$ hepi.ludiyati@polban.ac.id, ${ }^{3 *}$ Bagus.ppet@gmail.com, \\ 4yayasulaeman@gmail.com
}

\begin{abstract}
ABSTRAK
Beberapa tahun terakhir terjadi peningkatan penggunaan teknologi komunikasi WiFi dan teknologi komunikasi 5G. Kedua teknologi tersebut akan terus melayani kebutuhan manusia secara simultan. Oleh karena itu, sangat dibutuhkan sebuah peralatan yang mampu mengakomodasi kedua jaringan yang berada pada frekuensi kerja daerah ultra high frequency (UHF) dan super high frequency (SHF) tersebut dalam satu perangkat khususnya antena untuk meningkatkan efisiensi penggunaan perangkat. Pada makalah ini telah dilakukan perancangan dan simulasi sebuah antena yang bersifat dual-band menggunakan metode multi-patch dual-frequency antennas, serta penambahan metode truncated corner untuk menghasilkan polarisasi lingkaran. Dari hasil simulasi diperoleh bahwa antena mikrostrip dual-band dengan metode truncated corner memiliki frekuensi kerja 2,378 $\mathrm{MHz}$ dan $3540,8 \mathrm{MHz}$, bandwidth minimal $50 \mathrm{MHz}$, pola radiasi unidirectional, gain minimal $3 \mathrm{dBi}$, dan axial ratio mendekati 1,00 .
\end{abstract}

Kata kunci: axial ratio, dual-band, multi-patch dual-frequency antennas, $U H F, S H F$

\begin{abstract}
In recent years there has been an increase in the use of WiFi communication technology and $5 G$ communication technology. Both technologies will continue serve human needs simultaneously. Therefore, it is urgently needed equipment that can accommodate both networks that are in the working frequency of the ultra high frequency $(U H F)$ and super high frequency $(S H F)$ areas in one device, especially an antenna to increase the efficiency of the use of the device. In this paper, the design and simulation of a dual-band antenna have been carried out using the dual-frequency multi-patch antenna method, as well as the addition of the truncated corner method to produce circular polarization. From the simulation result, it is found that the dual-band microstrip antenna with the truncated corner method has a working frequency of $2.378 \mathrm{MHz}$ and $3540.8 \mathrm{MHz}$, minimum bandwidth $80 \mathrm{MHz}$, unidirectional radiation pattern, and minimum gain $5 \mathrm{dBi}$ and axial ratio close to 1.00.
\end{abstract}

Keywords: axial ratio, dual-band, multi-patch dual frequency antenna, UHF, SHF

\section{PENDAHULUAN}

Seiring perkembangan zaman, kebutuhan manusia akan teknologi komunikasi semakin tinggi. Saat ini dibutuhkan layanan telekomunikasi dengan kecepatan tinggi, handal, efisien dan efektif. Teknologi komunikasi saat ini yang sedang meningkat penggunaanya adalah teknologi komunikasi nirkabel (wireless). Teknologi ini menawarkan wireless fidelity (WiFi) [1] yang bekerja pada daerah ultra high frequency (UHF) dan teknologi generasi 5 (5G) [2] pada daerah super high frequency (SHF). Kedua teknologi ini memiliki kelebihan dan kelemahan masing-masing, namun dapat saling mendukung dalam sistem komunikasi jaringan wireless. Oleh karena itu, sangat dibutuhkan sebuah peralatan yang mampu mengakomodasi kedua jaringan yang berada pada frekuensi kerja daerah UHF dan SHF tersebut dalam satu perangkat khususnya antena.

Antena mikrostrip merupakan salah satu jenis antena popular yang digunakan dalam sistem telekomunikasi. Antena mikrostrip memiliki keunggulan dimensi yang kecil, desain yang kuat, dan 
mudah dimodifikasi [3]. Antena mikrostrip dengan sifat dual-band dapat menjadi solusi efisiensi agar antena mampu bekerja pada dua daerah frekuensi sekaligus dalam sebuah perangkat. Desain antena mikrostrip dual-band didapatkan dengan beberapa metode, yaitu multi-patch dual-frequency antennas, orthogonal mode dual-frequency patch antennas, dan reactively-loaded dual-frequency patch antennas [2]. Pada literatur [4], [5], dan [6] membuktikan bahwa penggunaan metode multi-patch dual-frequency antennas terbukti menghasilkan antena yang bekerja pada dua frekuensi dan penggunaan metode ini mudah untuk diimplementasikan. Multi-patch dual-frequency antennas adalah satu jenis antena mikrostrip yang mempergunakan lebih dari satu elemen antena dimana masingmasing elemen mempunyai frekuensi resonansi yang berbeda [4].

Umumnya antena mikrostrip menggunakan FR4-Epoxy dikarenakan mudah didapat dan harganya terjangkau namun permitivitas relatif yang dimiliki rendah. Oleh karena itu, pada penelitian ini dilakukan perancangan dan simulasi menggunakan bahan substrat lainnya yaitu rubber. Subrat rubber ditujukan untuk penggunaan bahan yang ramah lingkungan yaitu dengan memanfaatkan rubber/karet bekas, kemudian bahan yang digunakan bersifat lebih tahan lama. Terdapat beberapa penelitian seperti pada literatur [7] dan [8] yang juga menggunakan substrat berbahan rubber dengan jenis rubber yang berbeda-beda dan diterapkan pada aplikasi yang berbeda. Pada [7] dan [8] antena patch mikrostrip menggunakan substrat rubber dengan permitivitas pada 3,1 dan ketebalan 1,8 mm dikembangkan dengan return loss masing-masing pada $-30,92 \mathrm{~dB}$ dan $-18 \mathrm{~dB}$.

Penelitian ini mengusulkan rancangan antena mikrostrip berpolarisasi lingkaran pada daerah UHF dan SHF. Penelitian ini bertujuan untuk menghasilkan antena mikrostrip yang bersifat dual-band dengan metode multi-patch dual-frequency antennas dengan substrat rubber dan untuk mendukung efektivitas antena mikrostrip dilakukan modifikasi untuk menghasilkan polarisasi lingkaran sehingga antena dapat menerima gelombang sinyal dari segala arah dengan metode truncated corner. Penggunaan metode truncated corner ini digunakan karena telah terbukti pada penelitian [9] dan [10] dimana nilai axial ratio yang dihasilkan kurang dari $3 \mathrm{~dB}$. Teknik pencatu yang digunakan adalah proximity coupling untuk memperlebar bandwidth, namun pada penelitian ini tidak akan bahas lebih lanjut.

\section{METODE PENELITIAN}

Pada antena ini digunakan substrat rubber yang memiliki nilai ketebalan substrat $(h) 1 \mathrm{~mm}$, permitivitas relatif $\left(\varepsilon_{\mathrm{r}}\right) 3$ yang bersifat elastis, sedangkan patch, pencatu, dan ground plane-nya menggunakan kuningan dengan $0,2 \mathrm{~mm}$ dan konduktivitas $2,74 \times 10^{7} \mathrm{~S} / \mathrm{m}$. Adapun diagram alur perancangan antena ini diberikan pada Gambar 1 dan parameter antena yang ditargetkan ditampilkan dalam Tabel 1.
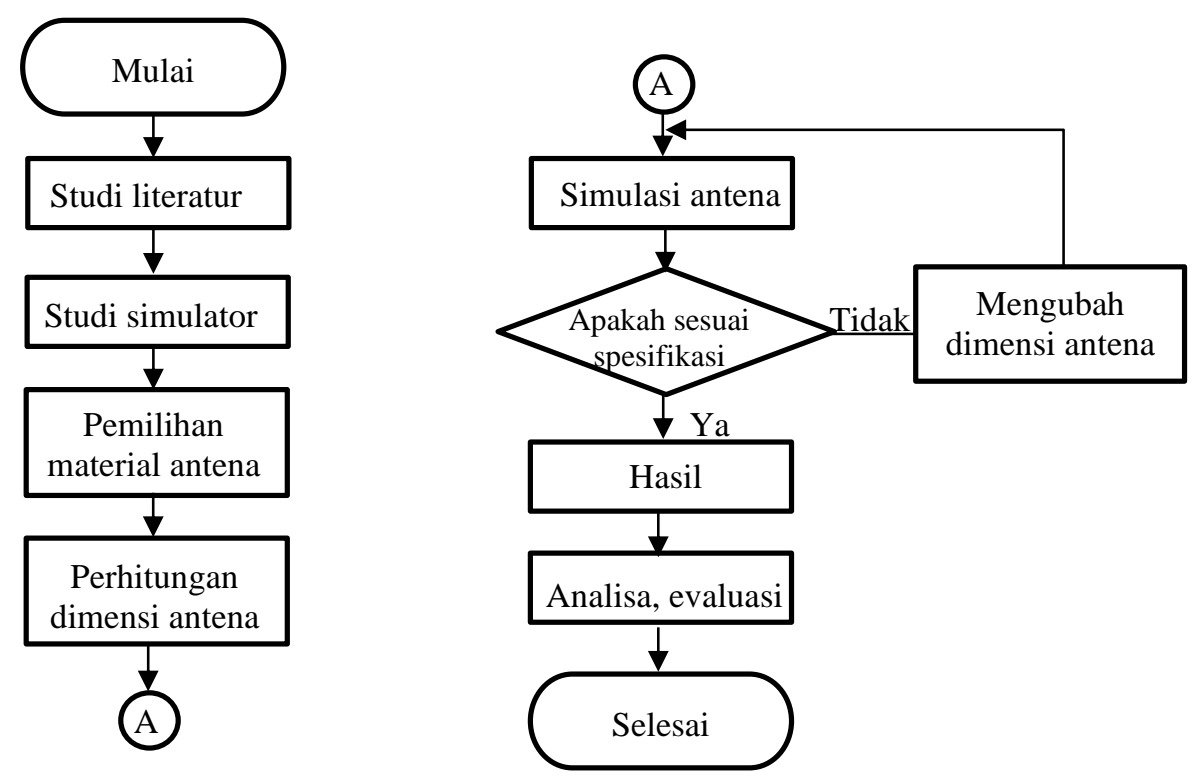

Gambar 1. Alur perancangan antena mikrostrip yang diusulkan 
Tabel 1. Parameter antena mikrostrip

\begin{tabular}{|l|c|}
\hline \multicolumn{1}{|c|}{ Parameter } & Keterangan \\
\hline Frekuensi kerja & $2,4 \mathrm{GHz}$ dan $3,5 \mathrm{Ghz}$ \\
\hline Bandwidth & $\geq 50 \mathrm{MHz}$ \\
\hline Return loss & $\geq 10 \mathrm{~dB}$ \\
\hline Gain & $\geq 3 \mathrm{dBi}$ \\
\hline Axial ratio & $1 \leq$ Axial ratio $\leq 2$ atau mendekati $0 \mathrm{~dB}$ \\
\hline
\end{tabular}

\subsection{Perhitungan Dimensi Antena}

Pada subbab ini dilakukan perhitungan dimensi bagian-bagian antena mikrostrip yaitu patch, microstrip line, substrat, dan ground plane menggunakan persamaan matematik berdasarkan pada literatur [11]. Pada penelitian ini, adanya fringing effect diabaikan sehingga persamaan matematik untuk menghitung lebar dari patch antena $\left(W_{p}\right)$ dan panjang patch antena $\left(L_{p}\right)$ menggunakan persamaan (1) berikut.

$$
W_{p}=\frac{c}{2 f r \sqrt{\frac{\left(\varepsilon_{r}+1\right)}{2}}}
$$

dengan $\varepsilon_{r}$ adalah konstanta dielektrik, $c$ adalah kecepatan cahaya, dan $f_{r}$ adalah frekuensi resonansi.

Persamaan matematik yang digunakan untuk menghitung lebar substrat dan ground plane antena $\left(W_{g}\right)$ ditunjukan pada Persamaan (2) dan persamaan matematik yang untuk menghitung panjang substrat antena dan ground plane antena $\left(L_{g}\right)$ ditunjukan pada Persamaan (3) berikut ini.

$$
\begin{gathered}
W_{g}=6 h+W_{p} \\
L_{g}=6 h+L_{p}+L_{f}
\end{gathered}
$$

dengan $L_{f}$ adalah panjang saluran.

Persamaan matematik untuk menghitung lebar saluran mikrostrip $50 \mathrm{Ohm}\left(W_{f}\right)$ ditunjukan pada Persamaan (4).

$$
W_{f}=\frac{2 h}{\pi}\left[B-1-\ln (2 B-1)+\frac{\varepsilon_{r}-1}{2 \varepsilon_{r}}\left(\ln (B-1)+0,39-\frac{0,61}{\varepsilon_{r}}\right)\right]
$$

dimana

$$
B=\frac{377 \pi}{2 Z o \sqrt{\varepsilon_{r}}}
$$

dengan Zo adalah impedansi saluran.

Persamaan matematik untuk menghitung panjang saluran mikrostrip $50 \mathrm{Ohm}\left(L_{f}\right)$ ditunjukan pada Persamaan (6).

dimana

$$
L_{f}=\frac{1}{4} \lambda_{g}
$$

$$
\begin{gathered}
\lambda_{g}=\frac{\lambda_{o}}{\sqrt{\varepsilon_{\text {reff }}}} \\
\lambda_{o}=\frac{c}{f}
\end{gathered}
$$

dengan $\lambda_{o}$ adalah panjang gelombang dan $\lambda_{g}$ adalah panjang gelombang guide pada saluran.

Polarisasi lingkaran pada antena mikrostrip ini didapatkan dengan metode truncated corner, yaitu pemotongan pada sudut patch persegi secara melintang sebesar $45^{\circ}$. Persamaan (9) digunakan untuk menghitung ukuran truncated corner [12]. 
dimana

$$
x=y=\frac{1}{2} \times \sqrt{2} \times r
$$

$$
r=\frac{1}{4} L_{p}
$$

dengan $x$ adalah sisi depan, $y$ adalah sisi samping, dan $r$ adalah sisi miring.

\section{HASIL DAN PEMBAHASAN}

Pada bab ini dipaparkan hasil dari simulasi yang telah dilakukan. Pada antena mikrostrip ini terdiri dari dua lapisan. Lapisan pertama merupakan substrat dan patch yang telah ditambah metode truncated corner dan lapisan kedua merupakan substrat, microtrip line, dan ground plane. Untuk desain dari antena yang telah disimulasikan diperlihatkan pada Gambar 2 dengan detail nilai dimensi antena yang dirangkum pada Tabel 2 .

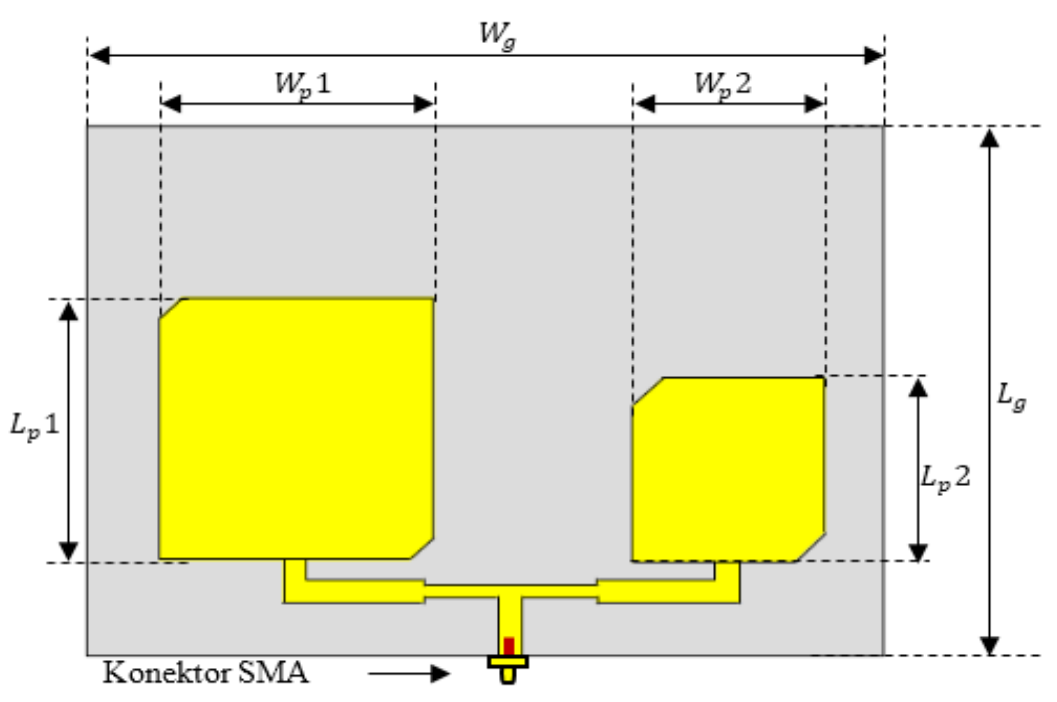

(a)

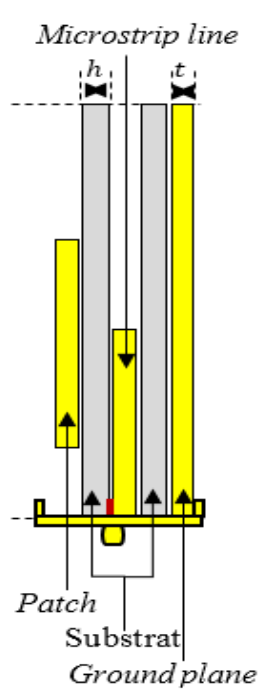

(b)

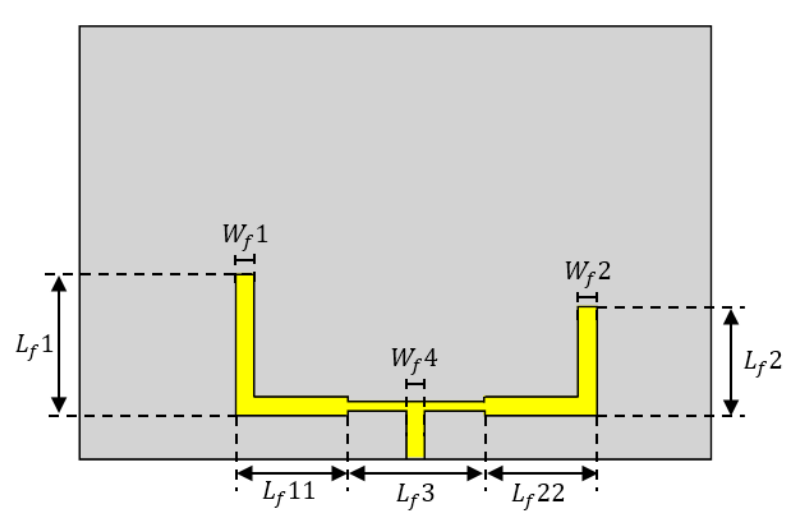

(c)

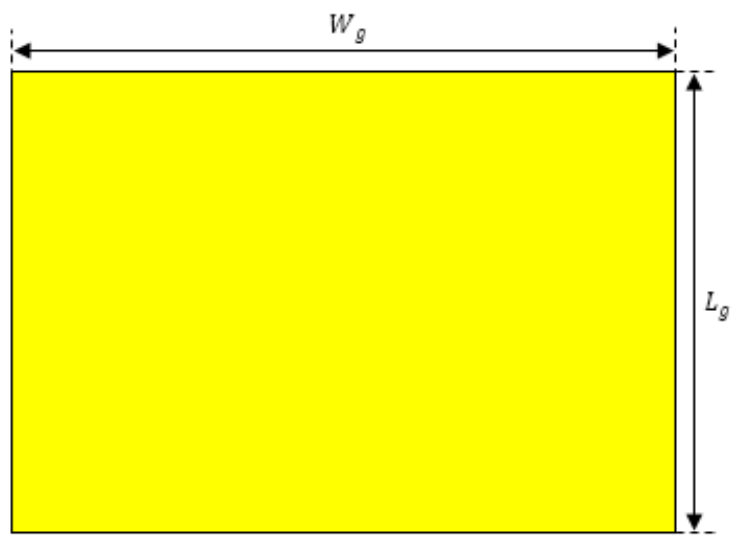

(d)

Gambar 2. Desain antena mikrostrip dual-band dengan penambahan metode truncated corner: (a) tampak dari atas lapisan 1, (b) tampak dari samping, (c) tampak dari atas lapisan 2, (d) tampak dari bawah lapisan 2 
Tabel 2. Dimensi antena mikrostrip setelah dioptimasi

\begin{tabular}{|c|c|c|}
\hline Keterangan & Simbol & $\begin{array}{c}\text { Ukuran } \\
\text { dimensi (mm) }\end{array}$ \\
\hline Tebal substrat & $h$ & 1,00 \\
\hline Tebal tembaga & $t$ & 0,15 \\
\hline Lebar dan panjang patch $2,4 \mathrm{GHz}$ & $W_{p} 1 / L_{p} 1$ & 36,3 \\
\hline Lebar dan panjang patch 3,5 GHz & $W_{p} 2 / L_{p} 2$ & 25,5 \\
\hline Lebar substrat dan ground plane & $W_{g}$ & 106,05 \\
\hline Panjang substrat dan ground plane & $L_{g}$ & 73,3 \\
\hline Lebar saluran 50 Ohm 2,4 GHz dan 3,5GHz & $W_{f} l \mid W_{f} 2$ & 3 \\
\hline Panjang saluran 50 Ohm 2,4 GHz & $L_{f} l$ & 24 \\
\hline Panjang saluran 50 Ohm 3,5 GHz & $L_{f} 11$ & 18,7 \\
\hline Lebar saluran 70,7 Ohm & $L_{f} 2$ & 18,3 \\
\hline Panjang saluran 70,7 Ohm & $L_{f} 22$ & 18,7 \\
\hline Lebar saluran input & $W_{f} 3$ & 1,55 \\
\hline Panjang saluran input 50 Ohm & $L_{f} 3$ & 23 \\
\hline Panjang saluran 50 Ohm 2,4 GHz & $W_{f} 4$ & 3 \\
\hline & $L_{f} 4$ & 8 \\
\hline & $W_{f} l \mid W_{f} 2$ & 3 \\
\hline & $L_{f} l$ & 24 \\
\hline
\end{tabular}

\subsection{Hasil Simulasi Antena Mikrostrip Dual-Band}

Pada subbab dipaparkan hasil simulasi antena mikrostip dual-band. Terdapat beberapa parameter yang dilakukan simulasi yaitu parameter- $S_{11}$, gain, dan axial ratio. Hasil simulasi antena mikrostip berupa grafik parameter- $S_{11}$ ditampilkan pada Gambar 3 berikut ini.

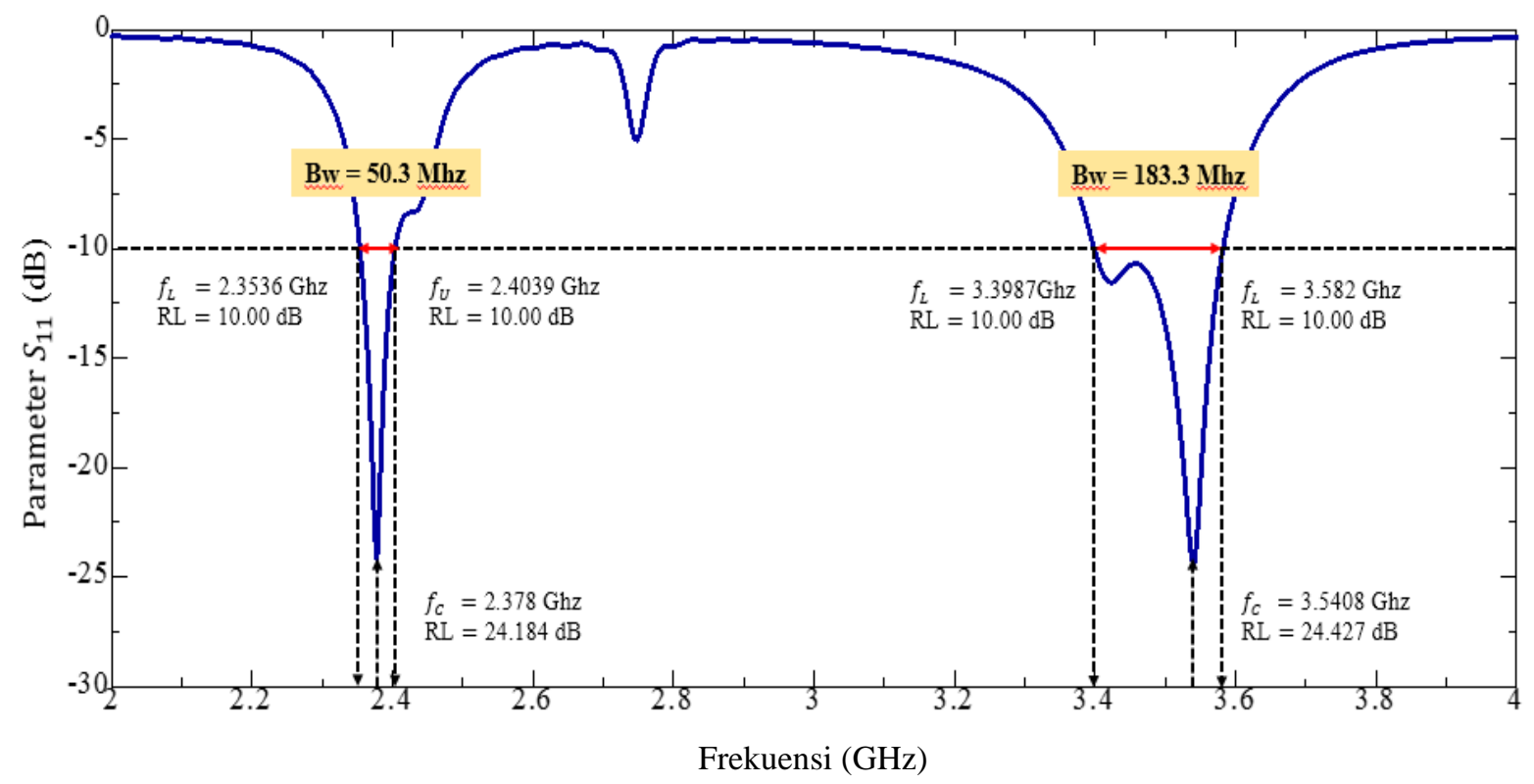

Gambar 3. Grafik parameter- $S_{11}$ fungsi frekuensi dari antena mikrostrip dual-band

Gambar 3 menunjukan nilai return loss yang didapatkan antena mikrostrip ini bernilai 24,18 dB pada frekuensi 2,378 MHz dan 24,42 dB pada frekuensi 3540,8 MHz. Nilai bandwidth didapatkan dengan cara menghitung selisih frekuensi atas dan frekuensi bawah pada return loss $10 \mathrm{~dB}$, sehingga berdasarkan hasil simulasi didapatkan nilai bandwidth 50,3 MHz dan $183 \mathrm{MHz}$ pada return loss $10 \mathrm{~dB}$ 
berturut-turut pada frekuensi UHF dan SHF. Hasil tersebut telah memenuhi parameter yang ditargetkan namun terjadi pergeseran frekuensi akibat penambahan metode truncated corner namun tidak signifikan.

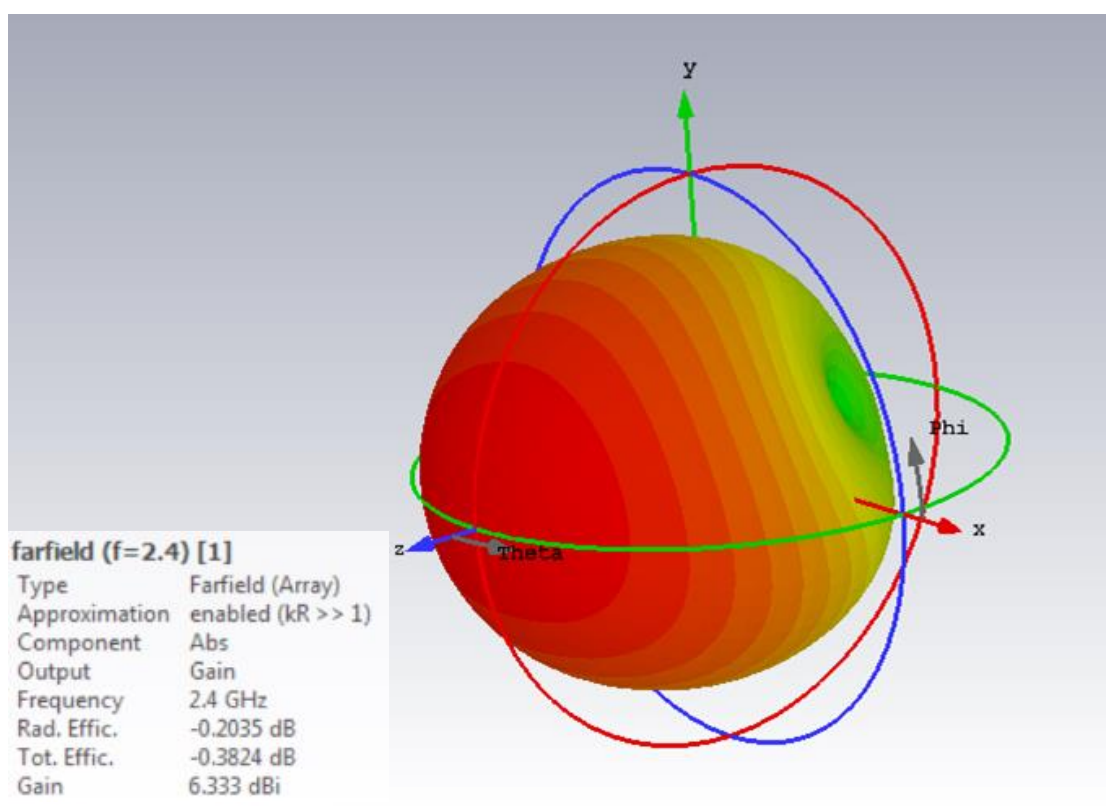

(a)

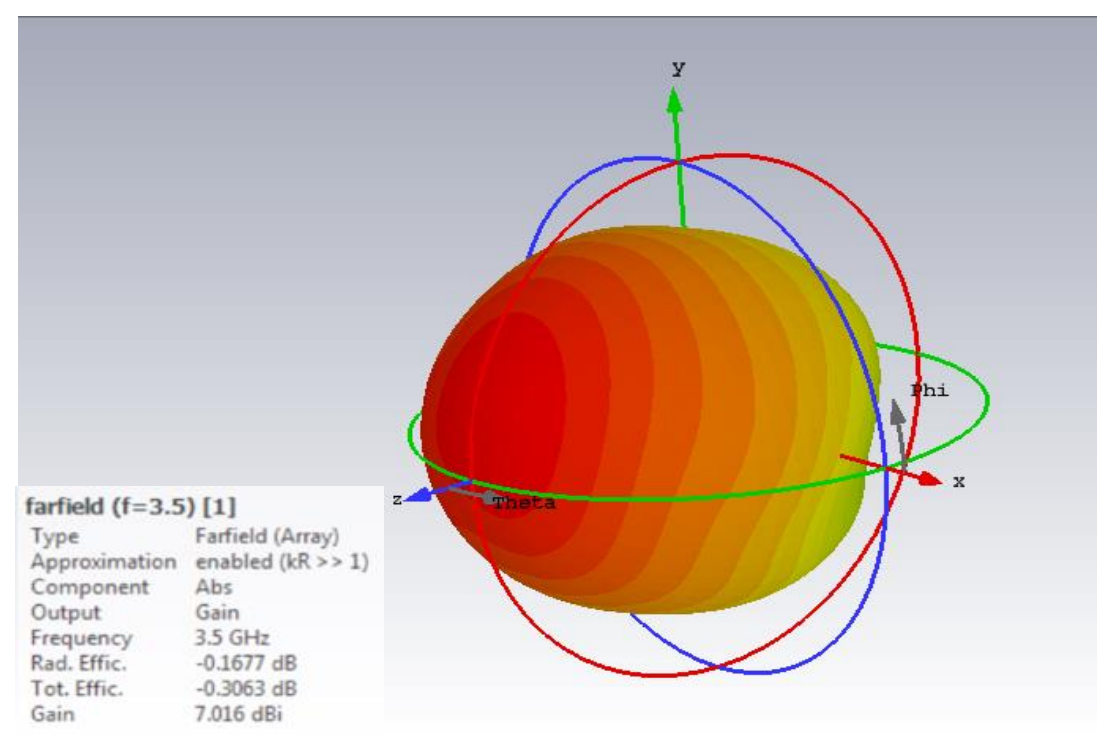

(b)

Gambar 4. Pola radiasi dan gain antena mikrostrip: (a) frekuensi 2,4 Ghz, (b) frekuensi 3,5 Ghz

Gambar 4 menunjukan antena mikrostrip yang dirancang memiliki pola radiasi unidirectional. Pada daerah UHF antena mikrostrip ini menghasilkan nilai gain sebesar 6,33 dBi, sedangkan pada daerah SHF antenna ini menghasilkan nilai gain sebesar 7,02 dBi. Nilai gain tersebut telah memenuhi parameter yang ditargetkan yaitu $>3 \mathrm{dBi}$. 


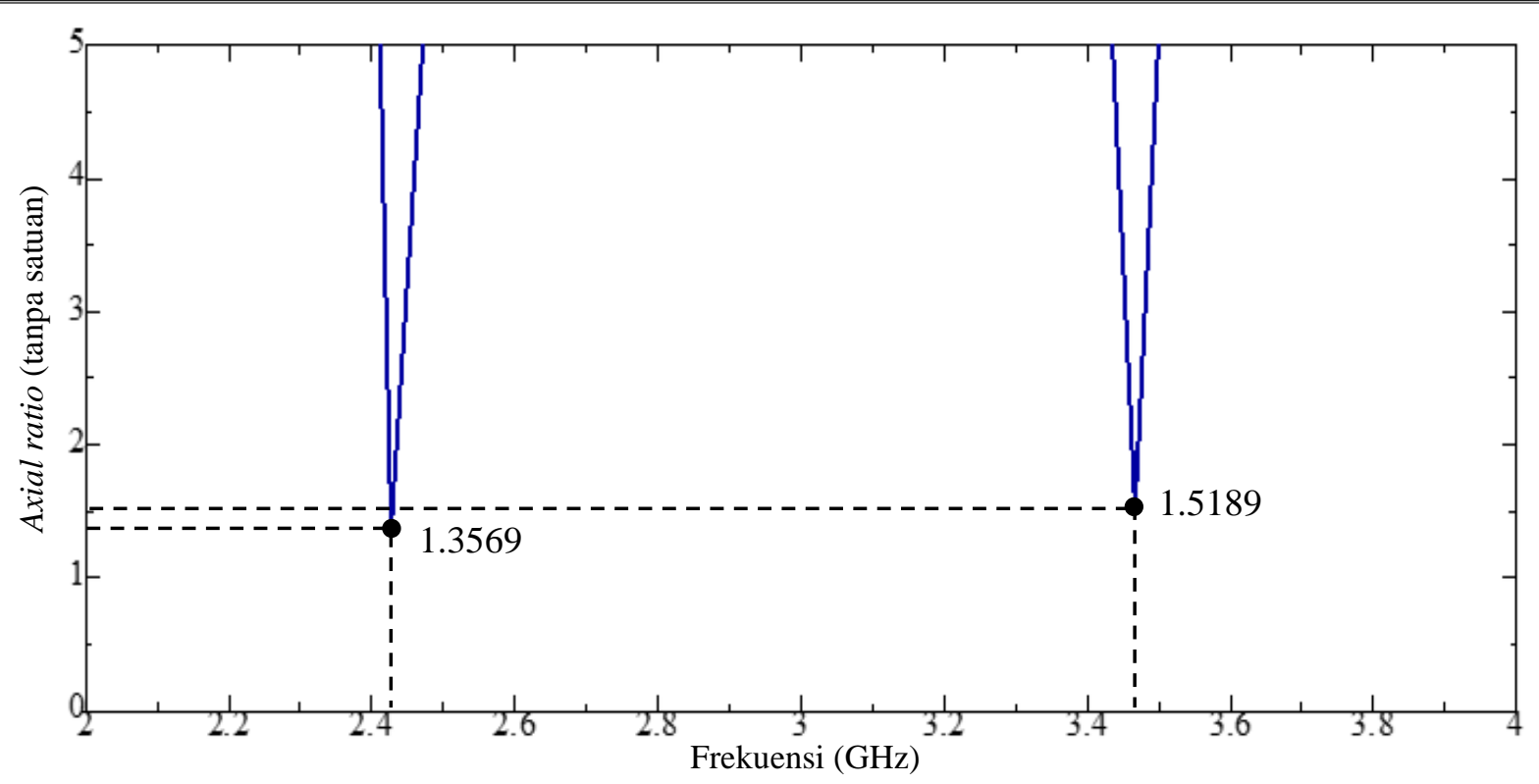

Gambar 4. Grafik axial ratio dari antena mikrostrip dual-band

Gambar 4 menunjukan nilai axial ratio yang dihasilkan antena mikrostrip. Nilai axial ratio ini merupakan perbandingan magnitudo medan listrik di arah vertikal $(\mathrm{phi}=0$ derajat) terhadap magnitudo medan listrik di arah horizontal (theta $=0$ derajat) yang keduanya saling tegak lurus dan tegak lurus pula dengan arah propagasi gelombang yang dihasilkan oleh antena. Pada kondisi ideal, nilai axial ratio dari sebuah antena berpolarisasi lingkaran adalah $0 \mathrm{~dB}$ atau 1,0. Namun untuk tataran praktis, kondisi ideal tersebut sulit didapatkan, sehingga disepakati bahwa axial ratio $<3 \mathrm{~dB}$ sudah dapat dikatakan berpolarisasi lingkaran [11]. Pada daerah UHF dan SHF berturut-turut dihasilkan nilai axial ratio $1,3569 \mathrm{~dB}$ dan $1,5189 \mathrm{~dB}$, yang mana nilai tersebut telah memenuhi syarat berpolarisasi lingkaran.

\section{KESIMPULAN}

Berdasarkan hasil simulasi antena mikrostrip yang didapatkan maka disimpulkan bahwa antena mikrostrip dapat bekerja pada dua daerah frekuensi, yaitu pada daerah UHF pada frekuensi 2353-2403 $\mathrm{MHz}$ yang memiliki frekuensi tengah $2378 \mathrm{MHz}$ dan daerah SHF pada frekuensi 3397-3582 MHz yang memiliki frekuensi tengah $3540,8 \mathrm{MHz}$. Hasil simulasi didapatkan nilai bandwidth pada daerah UHF dan SHF berturut- turut 50,3 MHz dan 183MHz. Antena ini memiliki nilai gain sebesar 6,33 dBi pada daerah UHF dan 7,02 dBi pada daerah SHF serta memiliki nilai axial ratio $\leq 3 \mathrm{~dB}$, sehingga dapat dikatakan antena ini berpolarisasi lingkaran. Dengan demikian, penelitian ini telah memenuhi parameter antena yang ditargetkan. Terdapat beberapa saran seperti pengunaan jenis patch lingkaran atau segitiga, jenis substrat yang lain, serta metode lain untuk menghasilkan antena bersifat dual-band sebagai bahan pembanding untuk pengembangan dalam penelitian selanjutnya.

\section{UCAPAN TERIMAKASIH}

Dalam penyelesaian penelitian ini, penulis mengucapkan terima kasih kepada Pusat Penelitian dan Pengabdian kepada Masyarakat (P3M) Politeknik Negeri Bandung atas dukungannya sehingga penelitian ini dapat terlaksana.

\section{REFERENSI}

[1] A. Meodia and M. R. D. Putri, "Penggunaan Wifi secara global meningkat selama pandemi corona," 1 April 2020. [Online]. Available: WWW.anatarnews.com. [Diakses 3 Maret 2021].

[2] "Ericsson Mobility Report: More than half a billion 5G subscriptions by the end of 2021," Telefonaktiebolaget LM Ericsson 1994-2021, 16 Juni 2021. [Online]. Available: www.ericson.com. [Diakses 11 Juli 2021].

[3] H. Hafidzah, "Perbandingan Desain Antena Mikrostrip Patch Tunggal," Jurnal Ilmiah Teknologi Rekayasa, vol. 21, no. 1, pp. 32-40, 2016. 
[4] R. R. K. Nisa, A. Atmaja, and H. Nugroho, "Rancang Bangun Antena Mikrostrip Segiempat Dual Band Dengan Menggunakan Teknik Pencatuan Proximity Coupled,” Jurnal JIT, vol. 3, no. 1, pp. 57-68, 2019.

[5] A. Atmaja, "Rancang Bangun Antena Mikrostrip Dual Band untuk Aplikasi LTE dan Wimax Menggunakan Teknik Pencatuan Proximity Coupled," in Prosiding SENTER 2019: Seminar Nasional Teknik Elektro 2019, 2019, pp. 211-219.

[6] F. Deriko and A. H. Rambe, "Rancang Bangun Antena Mikrostrip Array Patch Segiempat Dual-Band (2,3 GHz dan 3,3 GHz) Dengan Pencatuan Proximity Coupled," SINGUDA ENSIKOM, vol. 12, no. 32, pp. 1822, 2015.

[7] J. S. Chougule and D. U. V. Wali, "Design of Flexible Microstrip Antenna for Wearable Application," International Journal for Research in Emerging Science and Technology, vol. 2, no. 6, p. 144-147, 2015.

[8] J. Kurian, U. Rajan, and S. K. Sukumaran, "Flexible microstrip patch antenna using rubber substrate for WBAN applications," International Conference on Contemporary Computing and Informatics (IC3I), 2014, pp. 983-986.

[9] A. Syah and W. Hendrik, "Perancangan Antena Mikrostrip Truncated Corner Untuk Aplikasi Lte 2.300 Mhz Dengan Polarisasi Melingkar,” Jurnal Teknik dan Ilmu Komputer, vol. 06, no. 24, pp. 381-388, 2017.

[10] N. Kanawat and M. Kamon, "Corner Truncated Patch Circularly Polarized Antenna for UHF RFID Applications," in International Conference on Advances in Electrical, Electronics, Information, Communication and Bio-Informatics (AEEICB16), Thailand, 2018, pp. 433-436.

[11] C. A. Balanis, Antenna Theory Third Edition, Canada: John Wiley Sons, Inc, Hoboken, New Jersey, 2005.

[12] M. Z. Zulfikar, H. Ludiyati, and D. Saefudin, "Antena Mikrostrip MIMO $4 \times 4$ Frekuensi 1800MHz dengan Dielektrik Artifisial," Prosiding 11th Industrial Research Workshop and National Seminar (IRWNS), vol. 11, no. 1, 2020, pp. 656-662, 2020. 